\title{
UPAYA PENINGKATAN HASIL BELAJAR FISIKA KONSEP CAHAYA MELALUI PEMANFAATAN ALAT PERAGA BAGI SISWA KELAS VIII A SMPN 2 SAWANGAN MAGELANG JAWA TENGAH
}

\author{
GANGGIWATI \\ SMPN 2 Sawangan Kabupaten Magelang \\ e-mail: ganggiwati2305@gmail.com
}

\begin{abstract}
ABSTRAK
Alat peraga atau alat bantu mengajar adalah alat yang digunakan oleh seorang guru dalam mengajar. Alat peraga merupakan fasilitas penting dalam belajar karena bermanfaat untuk meningkatkan perhatian anak, dengan alat peraga anak diajak secara aktif memperhatikan apa yang diajarkan guru. Terlebih penggunaan alat peraga tersebut diikuti dengan metode anak aktif (anak membuat sendiri) maka efektifitas pembelajaran akan semakin baik, di samping itu anak akan mendapat kesempatan untuk mengembangkan kreatifitasnya. Belajar fisika dapat diartikan sebagai usaha/ akal yang dibuat/ dilakukan untuk menaikkan atau mempertinggi hasil perubahan tingkah laku/ sikap pada diri individu yang sedang belajar fisika untuk memperoleh pengetahuan fisika berdasar pengalaman, pemahaman dan ketrampilan yang dipelajaninya melalui percobaan dan pengukuran untuk menelusuri kebenaran suatu teori. Dengan adanya alat peraga pada pembelajaran fisika akan mempermudah proses belajar mengajar. Penelitian ini dibagi menjadi 2 siklus yaitu siklus I dan II. Seluruh data diperoleh melalui observasi, tes dan wawancara. Penerapan alat peraga dalam pembelajaran fisika ini dapat meningkatkan aktifitas dan partisipasi siswa dalam pembelajaran yaitu jumlah siswa yang aktif menjawab pertanyaan guru maupun dalam diskusi kelompok mencapai lebih dari $3,49 \%$ dari jumlah siswa yang hadir. Tidak hanya partisipasi dan aktifitas siswa yang meningkat akan tetapi persentase hasil belajar siswa juga mengalami peningkatan yang sangat signifikan yaitu sebelum siklus I hanya Sementara hasil belajar siswa juga meningkat yaitu dengan peningkatan persentase ketuntasan klasikal yaitu mengalami peningkatan nilai pembelajaran dari 64 setelah siklus I menjadi 66,36 dan menjadi 70,1 setelah siklus II.
\end{abstract}

Kata Kunci: Alat peraga, pembelajaran fisika, dan PTK

\section{PENDAHULUAN}

Perkembangan ilmu pengetahuan dan teknologi telah membawa perubahan pada hampir semua aspek kehidupan manusia yang begitu kompleks, dimana untuk memecahkan masalah tersebut hanya dapat dilakukan dengan penguasaan dan peningkatan ilmu pengetahuan serta tehnologi. Perubahan itu akan dapat bermanfaat apabila sumber daya manusia Indonesia mampu berperan dalam era persaingan global, oleh karena itu sumber daya manusia perlu ditingkatkan melalui berbagai upaya yang terencana, terarah, intensif, efektif dan efisien. Hanya melalui pendidikan kualitas sumber daya manusia dapat ditingkatkan.

Kinerja pendidikan nasional sampai saat ini belum mampu menunjukkan hasil yang memuaskan, relatif rendahnya prestasi belajar siswa menunjukkkan rendahnya kualitas pembelajaran. Hasil Ujian Nasional tahun 2005 melalui data Balitbang Depdiknas tingkat SMP dan MTs menunjukkan prosentase kelulusan 86,38\% dari 2.988 .733 peserta ujian. Diikuti dengan tahun 2006 sekalipun menunjukkan adanya peningkatan tapi tidak berarti prestasi akademis kita sudah memadai. Di forum internasional hal ini ditandai oleh prestasi kolektif siswa Indonesia yang masih relatif rendah, diantaranya pada forum Trends in International Mathematics and Science Study (TIMSS) 2003 yang dipublikasikan International Association for the Evaluation of Educational Achievement (IEA) USA, dari 44 negara partisipan ternyata untuk prestasi IPA masih berada pada urutan ke 37. Sekalipun secara individual beberapa siswa kita menunjukkan prestasinya tetapi secara kolektif lebih banyak gagalnya yang diperoleh melalui forum IMO, IPhO, APAU dan sejenisnya. Belum lagi juara Olympiade, tidak lulus ujian Nasional ataupun peserta yang lulus Ujian Masuk 


\section{STRATEGY : Jurnal Inovasi Strategi dan Model Pembelajaran Vol 1. No 1. Juli Tahun 2021 e-ISSN : 2798-5466 P-ISSN : 2798-5725}

Perguruan Tinggi ternyata Ujian Nasionalnya tidak lulus, ini sungguh ironis tetapi kita harus menerima kenyataan tersebut. Rendahnya mutu pendidikan di Indonesia, di forum internasional maupun prosentase lulusan yang belum sesuai target yang diharapkan, mengundang para pakar pendidikan untuk mengkaji ulang bagaimana sistem pendidikan di negara kita berlangsung. Begitu juga dengan hasil ujian ataupun hasil belajar IPA di Kabupaten Magelang khususnya di sekolah kami SMP Negeri 2 Sawangan Kabupaten Magelang belum menunjukkan hasil yang memuaskan.

Sistem pendidikan nasional harus mampu menjamin pemerataan kesempatan pendidikan peningkatan mutu serta relevansi dan efisiensi managemen pendidikan untuk menghadapi tantangan sesuai dengan tuntutan perubahan kehidupan lokal nasional dan global sehingga perlu dilakukan pembaharuan pendidikan secara terencana terarah dan berkesinambungan. Pendidikan adalah usaha sadar dan terencana untuk mewujudkan suasana belajar dan proses pembelajaran agar peserta didik secara aktif mengembangkan potensi dirinya untuk memiliki kekuatan spiritual keagamaan, pengendalian diri kepribadian, kecerdasan, akhlak mulia serta ketrampilan yang diperlukan dirinya, masyarakat, bangsa dan negara. Menurut UU RI Nomor 20 tahun 2003 pasal 40 menyebutkan bahwa Pendidik dan Tenaga Kependidikan berkewajiban menciptakan suasana pendidikan yang bermakna, menyenangkan, kreatif, dinamis, dan dialogis, mempunyai komitmen secara profesional untuk meningkatkan mutu pendidikan, memberi teladan dan menjaga nama baik lembaga profesi dan kedudukan sesuai dengan kepercayaan yang diberikan kepadanya. Pendidikan merupakan bentuk investasi jangka panjang, karena melalui pendidikan dapat membekali seseorang berbagai pengetahuan ketrampilan nilai dan sikap yang diperlukan untuk dapat bekerja secara produktif.

Pendidikan lebih ditujukan pada proses yang berlangsung dalam pembelajaran bukan semata pada produk akhir berupa hasil belajar peserta didik. Ilmu Pengetahuan Alam berkaitan dengan cara mencari tahu tentang alam secara sistematis, hingga IPA bukan hanya penguasaan kumpulan pengetahuan yang berup fakta-fakta, konsep, atau prinsip- prinsip saja tetapi juga merupakan proses penemuan. Proses pembelajarannya menekankan pada pemberian pengalaman langsung untuk mengembangkan kompetensi agar menjelajahi dan memahami alam sekitar secara ilmiah. Kurikulum IPA SMP juga memberikan pembelajaran Salingtemas (Science Lingkungan Tehnologi dan Masyarakat). Secara terpadu yang diarahkan pada pengalaman belajar untuk merancang dan membuat suatu karya melalui penerapan IPA dan kompetensi bekerja ilmiah secara bijaksana.

Pembelajaran IPA sebaiknya dilaksanakan secara inkuiry ilmiah (Scientific inquiry) untuk menumbuhkan kemampuan berfikir bekerja dan bersikap ilmiah serta mengkomunikasikan sebagai aspek penting kecakapan hidup. Standar Kompetensi (SK) dan Kompetensi Dasar (KD) merupakan standar minimum yang secara nasional harus dicapai peserta didik dan menjadi acuan dalam pengembangan kurikulum disetiap satuan pendidikan. Pencapaian SK dan KD didasarkan pada pemberdayaan peserta didik untuk membangun bekerja ilmiah dan pengetahuan sendiri yang difasilitasi oleh guru.

Relatif rendahnya hasil belajar IPA yang ditunjukkan oleh hasil ujian maupun tes pengendali mutu di sekolah kami menggugah guru-guru IPA untuk melakukan penelitian tindakan kelas melalui peningkatan proses pembelajaran yang pada ujungnya pencapaian KKM ataupun peningkatan hasil belajar IPA. Kondisi ini harus segera diatasi, karena meskipun kegiatan atau proses belajar mengajar sudah diawali dengan perencanaan melalui persiapan mengajar dengan penyusunan Rencana Pembelajaran, akan tetapi pada kenyataannya belum sepenuhnya dapat terlaksana sesuai rencana atau tujuan belum tercapai. Masih banyaknya dijumpai proses pembelajaran IPA yang belum mengoptimalkan penggunaan/ pemberdayaan sarana prasarana yang ada di sekolah ataupun di lingkungan sekitar sekolah. Banyaknya metode pembelajaran yang belum memberdayakan siswa dalam keikutsertaannya mengetahui segala potensi yang dimiliki oleh siswa, dengan memberdayakan siswa, siswa akan belajar mengetahui (learning to know), belajar sambii 


\section{STRATEGY : Jurnal Inovasi Strategi dan Model Pembelajaran Vol 1. No 1. Juli Tahun 2021 e-ISSN : 2798-5466 P-ISSN : 2798-5725}

melakukan percobaan (learning to do), belajar untuk mengenal diri sendiri (learning to learn), belajar untuk dapat hidup bersama (learning to life together). Beberapa pendidik belum mampu menciptakan suasana pendidikan yang bermakna, menyenangkan, kreatif, dinamis dan dialogis sesuai dengan yang diisyaratkan UU RI Nomor: 20 tentang Sistem Pendidikan (Pasal 40: 2).

Menurut Arsyad (dalam Aziz, 2006), media adalah segala bentuk dan saluran yang digunakan untuk menyampaikan pesan atau informasi, sedangkan pengertian alat peraga adalah alat bantu yang digunakan oleh guru dalam proses belajar mengajar agar proses belajar siswa lebih efektif dan efisien (Sambudi, 2009) mengemukakan bahwa dengan memanfaatkan media pengajaran atau alat peraga dalam proses pembelajaran dapat membangkitkan keinginan dan minat yang baru, serta dapat memotivasi dan merangsang belajar siswa, bahkan dapat membawa pengaruh-pengaruh psikologis terhadap siswa. Oleh karena itu penelitian tindakan kelas ini diharapkan dengan adanya alat peraga bisa membantu siswa dalam memahami konsep cahaya dalam pembelajaran fisika.

\section{METODE PENELITIAN}

Sumber data dalam penelitian tindakan kelas ini diperoleh dari siswa sebagai subyek yang merupakan sumber primer. Sumber primer yang dimaksud dibedakan menjadi 2, yaitu sumber data primer yang berupa hasil belajan yang meliputi hasil belajan kondisi awal, hasil belajar akhir siklus I dan hasil belajar akhir siklus II. Data yang diperoleh dari kondisi awal yaitu daftar nilai sebelum materi cahaya untuk kelas VIII A. Data yang diperoleh pada akhir siklus 1 yang berupa nilai hasil tes dari materi yang penyajiannya dengan alat peraga yang digunakan secara kelompok. Data yang diperoleh pada akhir siklus ke 2 yang berupa nilai hasil tes dari materi yang penyajianya dengan alat peraga yang digunakan secara individu. Terdapat 2 teknik untuk mengumpulkan data yaitu melalui tehnik tes dan non tes. Dalam penelitian ini, peneliti tidak akan menggunakan kedua-duanya yaitu teknis tes dan non tes tetapi hanya akan menggunakan salah satu diantaranya yaitu teknik tes tertulis. Teknik tes tertulis digunakan karena dalam penelitian ini yang diukur adalah hasil belajar. Alat pengumpulan data pada penelitian ini disesuaikan dengan teknik pengumpulan data, karena teknik pengumpulan data dalam penelitian ini menggunakan tehnik tes tertulis maka alat yang digunakan berupa butir-butir soal. Penulisan butir soal diawali dengan penyusunan kisi-kisi, baik kisi-kisi soal siklus I maupun kisi- kisi soal akhir siklus II.

Langkah awal sebelum kami melakukan penelitian adalah menetapkan metode yang akan dilakukan. Metode penelitian dibedakan menjadi 2 yaitu metode kualitatif dan metode kuantitatif. Penelitian yang kami lakukan adalah penelitian tindakan kelas, adapun salah satu ciri penelitian mi adalah melalui siklus. Sebingga langkah berikutnya adalah menetapkan sikius, peneliti menetapkan bahwa penelitian mi terdiri dan 2 sikius. Tiap siklus terdiri dari 4 tingkatan/tahapan yakni : Perencanaan (Planning), Tindakan (Acting), Pengamatan (Observing) dan Refleksi (Reflecting) (Arikunto dkk,2010).

\section{HASIL DAN PEMBAHASAN}

Sampai saat ini Fisika masih dianggap merupakan mata pelajaran sulit. Hal ini ditandai dengan relatif rendahnya hasil belajar IPA yang ditunjukkan oleh hasil ujian ataupun tes pengendali mutujuga hasil ulangan harian. Kondisi ini mungkin disebabkan oleh masih banyaknya dijumpai proses pembelajaran yang belum mengoptimalkan penggunaanl pemberdayaan sarana prasarana yang ada di sekolah maupun lingkungan sekolah atau belum memanfaatkan alat peraga dan relatif minimnya alat peraga yang ada di sekolah. Pemberdayaan siswa dalam pembuatan alat peraga dapat mengembangkan kreatifitas, inovasi dan cara berfikir ilmiah juga mengembangkan kemampuan kognitif dan psikomotorik. Pemanfaatan alat peraga secara kelompok atau individu akan membangkitkan motivasi dan antusias siswa selama proses pembelajaran berlangsung. Disamping itu kemampuan guru 
dalam mengembangkan memanfaatkan alat peraga atau alat bantu dan media pembelajaran merupakan refleksi dan akuntabilitas profesionalisme guru.

Pembelajaran IPA lebih menekankan pada pemberian pengalaman langsung untuk mengembangkan kompetensi agar memahami dan menjelajahi alam sekitar secara ilmiah. Untuk itulah peneliti termotivasi untuk mengadakan penelitian dengan judul Upaya Peningkatan Hasil Belajar Fisika konsep cahaya bagi siswa kelas VIII A SMP N 2 Sawangan pada Semester Genap Tahun Pelajaran 2006/2007. Dengan pemanfaatan alat peraga pada konsep cahaya anak lebih mudah memahami materi karena anak dapat melihat langsung bukan hanya sekedar mendengar penjelasan dari guru. Dengan demikian kesulitan belajar siswa khususnya konsep cahaya dapat segera diatasi, sehingga akan berpengaruh pada pemahaman siswa dan pada akhirnya hasil belajar Fisika atau IPA pada umumnya akan rendahnya hasil belajar seperti diperlihatkan dalam tabel di bawah ini:

Tabel 1. Nilai Kondisi Awal

\begin{tabular}{|l|l|l|}
\hline No & Uraian & Kondisi Awal \\
\hline 1 & Nilai Terendah & 22 \\
2 & Nilai Tertinggi & 92 \\
3 & Nilai Rata-rata & 64,081 \\
\hline
\end{tabular}

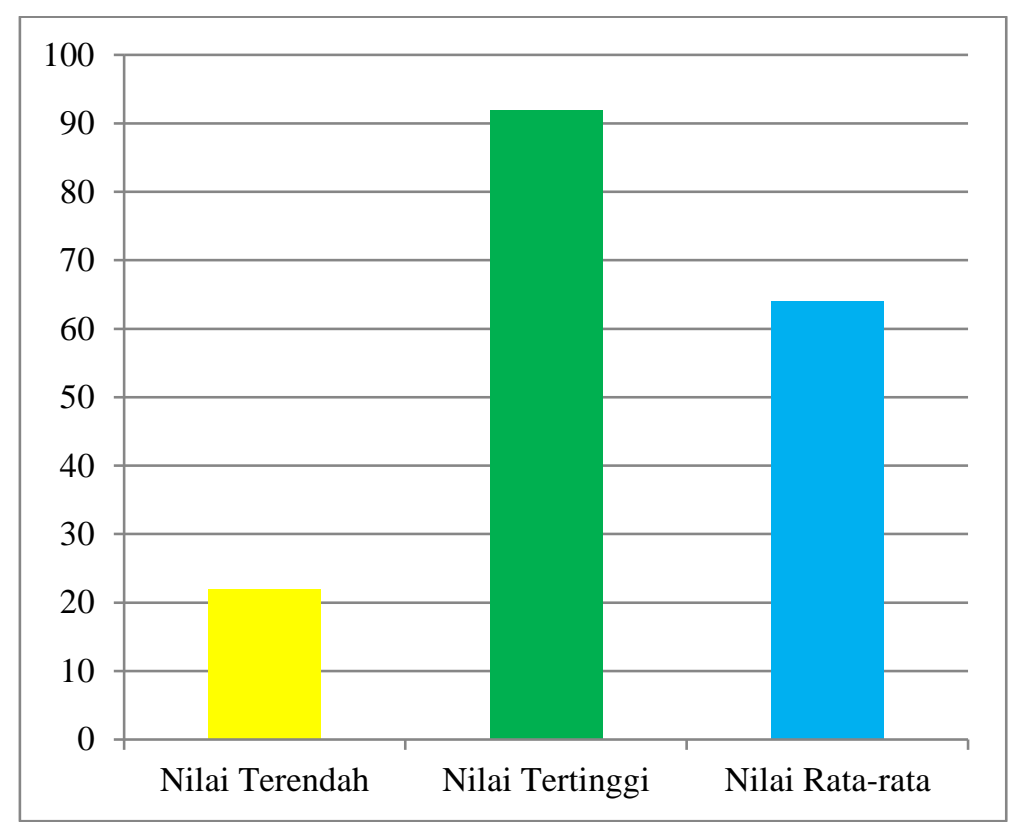

Gambar 1. Grafik Hasil Ulangan Kondisi Awal Hasil Siklus I

Berdasarkan hasil ulangan Siklus I diperoleh data:

Tabel 2 Hasil Ulangan Siklus I

\begin{tabular}{|l|l|l|}
\hline No & Uraian & Kondisi Awal \\
\hline 1 & Nilai Terendah & 29 \\
2 & Nilai Tertinggi & 93 \\
3 & Nilai Rata-rata & 66,32 \\
\hline
\end{tabular}




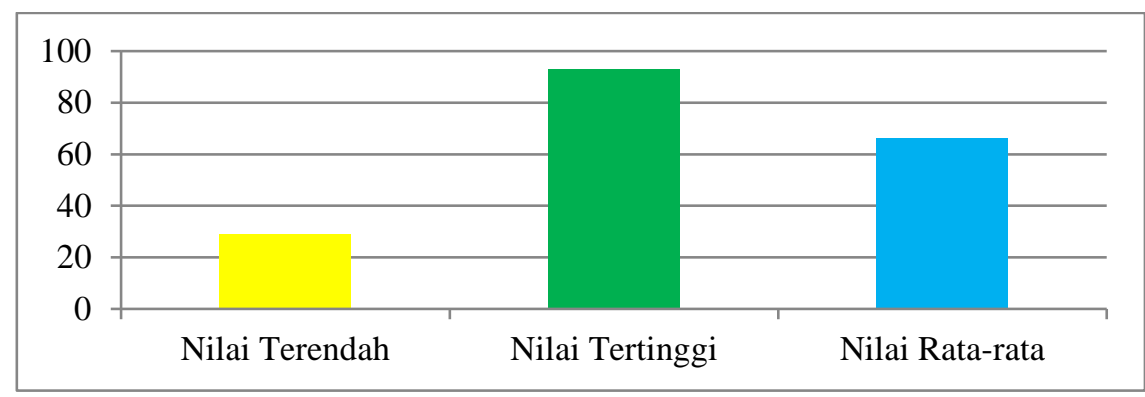

Gambar 2. Grafik Hasil Ulangan Siklus I

Adapun interval nilai hasil ulangan Siklus 2 seperti dalam tabel di bawah ini:

Tabel 3. Ulangan Harian Siklus I

\begin{tabular}{|l|l|l|}
\hline No & Interval & Frekuensi \\
\hline 1 & $84-93$ & 5 \\
2 & $73-83$ & 6 \\
3 & $62-72$ & 7 \\
4 & $51-61$ & 10 \\
5 & $40-50$ & 5 \\
6 & $29-30$ & 1 \\
\hline & Jumlah & 37 \\
\hline
\end{tabular}

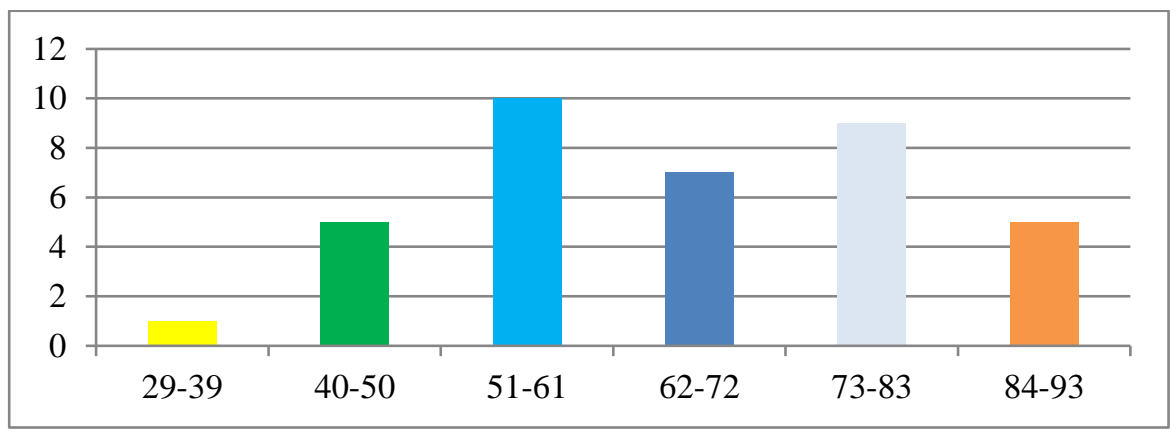

Gambar 3. Grafik Interval Hasil Ulangan Harian Siklus I

Berdasarkan nilai tes yang kita sajikan maka dapat kita tentukan nilai rata-rata sebagai berikut:

$$
\bar{X}=\frac{\sum X}{n}
$$

Keterangan :

1. $\bar{X}=$ nilai rata-rata

2. $\sum=$ simbol jumlah 
3. $X=$ nilai/data

4. $\mathrm{n}$ = banyaknya siswa / subyek

$\bar{X}=\frac{2454}{27}$

$=66,32$

Ternyata dengan memanfaatkan alat peraga jumlah siswa yang mengantuk tidak ada. Hal ini dapat terjadi karena proses pembelajaran dengan memanfaatkan alat peraga akan dapat memusatkan perhatian anak pada alat peraga yang digunakan sehingga materi pelajaran lebih mudah difahami dan akan lebih mengesan dalam ingatannya dibandingkan dengan hanya mendengar penjelasan guru. Disamping itu anak lebih aktif dan lebih antusias selama pembelajaran berlangsung dan yang lebih prinsip lagi proses pembelajaran semakin berkualitas.

\section{Siklus II}

Berdasarkan data hasil ulangan harian Siklus II tentang pembiasan cahaya diperoleh data sebagai berikut:

Tabel 4. Hasil Ulangan Harian Siklus 2

\begin{tabular}{|l|l|l|}
\hline No & Uraian & Kondisi Awal \\
\hline 1 & Nilai Terendah & 40 \\
2 & Nilai Tertinggi & 95 \\
3 & Nilai Rata-rata & 70,14 \\
\hline
\end{tabular}

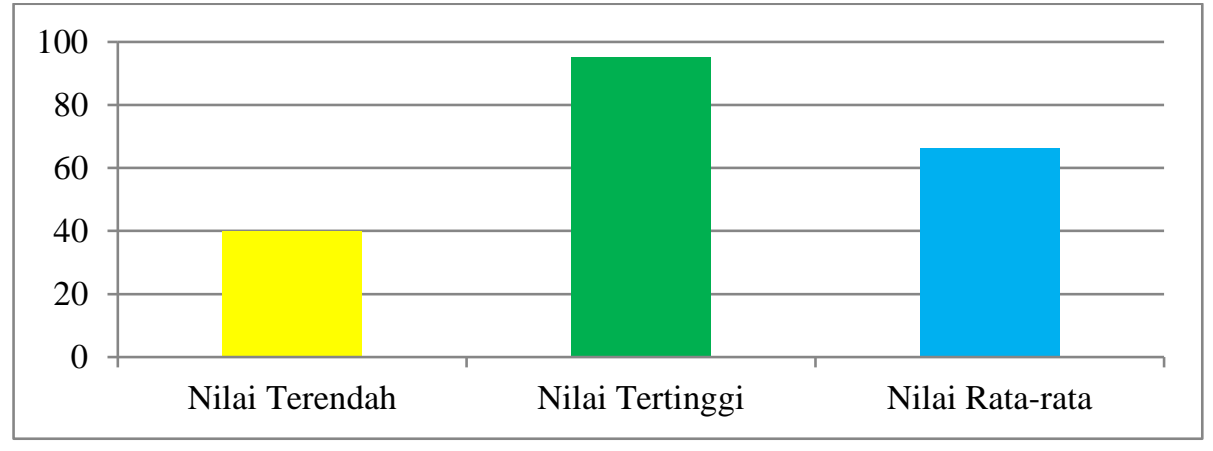

Gambar 4. Diagram Hasil Ulangan Siklus II

Tabel 5. Ulangan Harian Siklus I

\begin{tabular}{|l|l|l|}
\hline No & Interval & Frekuensi \\
\hline 1 & $95-100$ & 1 \\
2 & $84-93$ & 6 \\
3 & $73-83$ & 7 \\
4 & $62-72$ & 13 \\
\hline
\end{tabular}




\begin{tabular}{|l|l|l|}
\hline 5 & $51-61$ & 8 \\
6 & $40-50$ & 2 \\
\hline
\end{tabular}

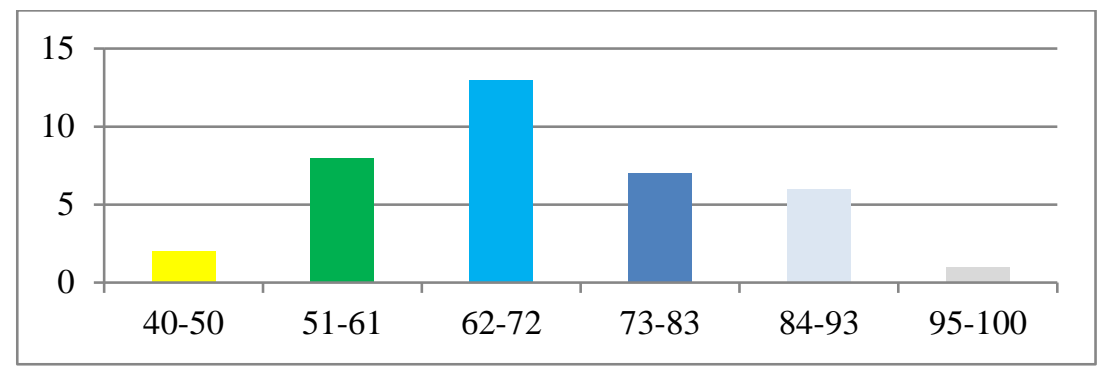

Gambar 5. Grafik Interval Ulangan Harian II

Dengan memanfaatkan alat peraga yang digunakan secara individu di samping siswa tidak ada yang mengantuk, siswa cenderung aktif melakukan kegiatan dengan kelompoknya. Di samping itu siswa lebih antusias dan betul-betul menikmati materi yang sedang dipelajari tentang pembiasan cahaya, bahkan sebagian besar siswa banyak yang menanyakan beberapa hal yang ditemui selama melakukan kegiatan, ini terjadi karena siswa menjadi sangat tertarik dengan materi pembiasan sekalipun materi ini sebetulnya sulit.

\section{KESIMPULAN}

Dengan membandingkan hasil dari proses belajar kondisi awal dengan akhir siklus I, maupun akhir siklus I dengan siklus II juga kondisi awal dan akhir siklus II ternyata menunjukkan bahwa proses pembelajaran Konsep Cahaya dengan memanfaatkan alat peraga baik yang digunakan secara kelompok maupun individu dapat meningkatkan pemahaman dan penguasaan materi bahan ajar juga minat dan aktivitas siswa. Dengan demikian dapat disimpulkan bahwa pembelajaran menggunakan alat peraga merupakan salah satu strategi pembelajaran untuk meningkatkan hasil belajar Fisika Konsep Cahaya bagi siswa kelas VIII A SMP N 2 Sawangan Kabupaten Magelang pada Semester Genap Tahun pelajaran 2006/2007.

\section{DAFTAR PUSTAKA}

Adenan. 1983. Puzzles and Games for Students of FKIP. Yokyakarta Kanesius

Ali, M.1998. Strategi Penelitian Pendidikan. Bandung. Angkasa

Arikunto, Suharsimi. 2010. Penelitian Tindakan Kelas :PT.Bumi Aksara

Arsyad, Azhar. 2005. Media Pembelajaran. Jakarta: PT Raja Grafindo Persada.

Dahar, Ratna Wilis. (1988). Teori Teori Belajar. Bandung: Erlangga

Depdikas 2016 .Peraturan Menteri Pendidikan dan Kebudayaan Nomor 21 tahun 2016

Tentang Standar Isi Pendidikan Dasar dan Menengah.Jakarta : Depdiknas

Hisyam, Zaini. (2008). Srategi pembelajaran aktif. Yogyakarta: Insan Mandiri

Sudjana, N. (2014). Penelitian Hasil Proses Belajar Mengajar. Bandung: Remaja Rosdakarya.

Sundayana. (2014). Media dan Alat Peraga Dalam Pembelajaran Matematika. Bandung: Alfabeta.

Undang-Undang Republik Indonesia Nomor 20 tahun 2003 tentang Sistem Pendidikan. 